\title{
Physiological Quality of Stored Dipteryx alata Vogel Seeds: Tetrazolium Test and Radiographic Imaging Standardization
}

\author{
Glicélia Pereira Silva ${ }^{1}$ \\ Juliana de Fátima Sales ${ }^{1}$ \\ Jacson $\mathrm{Zuchi}^{1}$ \\ Kelly Juliane Telles Nascimento ${ }^{1}$ \\ Lílian Abadia da Silva ${ }^{1}$ \\ Moara Mariely Vinhais Souza ${ }^{1}$ \\ Arthur Almeida Rodrigues ${ }^{1}$ (D)
}

${ }^{1}$ Instituto Federal Goiano de Educação, Ciência e Tecnologia (IFGoiano), Laboratório de Sementes, Campus Rio Verde, Rio Verde, GO, Brasil.

\begin{abstract}
The baru (Dipteryx alata Vogel), is fruit tree displaying economic, environmental, industrial and food importance. The objective of this study was to adapt to the tetrazolium test methodology to baru seeds and evaluate the physiological quality of seeds stored for 12 months at 10 and $20{ }^{\circ} \mathrm{C}$, using X-ray images as a toll for detection damage throughout the storage period while also carrying out germination, emergence and electrical conductivity tests. Baru seeds remained viable for 12 months of storage, albeit with a small decrease in vigor after nine months. The applied tetrazolium test methodology was efficient in determining internal seed damage. The pre-soak time for the tetrazolium test and solution concentration was 24 hours and $0.05 \%$. No changes in seed morphology and radiographic images were observed during the storage periods, regardless of the assessed temperature. The X-ray test enabled a precise visualization of internal baru seed structures.
\end{abstract}

Keywords: Storage, baru, Viability, X-ray, vigor.

\section{INTRODUCTION AND OBJECTIVES}

The baru (Dipteryx alata Vogel) is a native species from the Cerrado domain, a fruit displaying high potential, used as a food item and in the medicinal and industrial areas. Its seeds present high nutritional value, with high protein and essential amino acid content, as well as considerable amounts of calcium, zinc, iron and fiber, thus considered an excellent dietary ingredient (Fernandes et al., 2010). Another important factor contributing to baru valuation is the fact that it is an excellent soil nitrogen fixator (Mota et al., 2012). This species belongs to the Fabaceae family and has been applied in recovery and planting areas aiming at pasture enrichment. It has wide distribution, especially in the drier regions (Oliveira et al., 2006; Soares et al., 2008). However, due to agro-industrial activity advances and human occupation of the Cerrado domain, the Cerrado territory has become fragmented, leading to vegetation restriction and habitat loss for various species (Klink \& Machado, 2005; Brannstrom et al., 2008; Carvalho et al., 2009), including the baru.
Seed physiological quality, longevity and vigor are determining factors to ensure germination and seedling formation success, as well as plant species preservation. In this sense, orthodox seeds have mechanisms that favor their survival in different conditions. Fact, which contributes to understanding the behavior of seeds during storage (Bragante et al., 2018). The seeds of species of the Fabaceae Family, give most of them, an orthodox character. Tolerating prolonged periods of storage with a water content of approximately $5 \%$ (Freitas et al., 2019). However, there are few works with Dipteryx alata Vogel that describe the characteristics of seeds in this regard.

Therefore, it is important to create strategies to assess the viability of seeds. Maximizing the storage process to ensure minimal deterioration and loss of characteristics (Toledo et al., 2009). These strategies include factors that can be controlled in storage environments, such as in a temperature and humidity control chamber (type BOD).

It is widely recognized that storage is a viable means of maintaining seed physiological quality and guiding their 
behavior over time, becoming especially important in contributing to the conservation of genetic information, leading to species preservation (Walters et al., 2005). Several techniques have been tested during seed storage targeting at metabolism conservation and reduction and aiming at high vigor maintenance, such as low water content and reduced temperature conditions (Kohama et al., 2006).

Different tests can be performed to evaluate seed vigor (Abreu, 2011; Alves, 2012), although all require specific species standardization. The tetrazolium test, based on tissue viability via respiratory activity (França Neto, 1998; Azerêdo et al., 2011), is noteworthy in this regard. X-ray imaging is also efficient in evaluating seed vigor, as it is an accurate, fast and non-destructive method that allows for the detection of internal seed damage.

$\mathrm{X}$-ray imaging allows for the visualization of damage potentially caused by malformations due to harvesting, drying or insect attacks (Cícero \& Júnior, 2003; ISTA, 2004; Pinto et al., 2007). It is important to note that seeds without full internal structure development increase the chances of low vigor seedling development or no development at all (Burg et al., 1994; Carvalho \& Nakagawa, 2012). This technique is promising and aids in the selection of high-quality seeds which will, in turn, lead to best seedling development (Pinto et al., 2012; Lima et al., 2013). However, efficient, X-ray testing, as well as tetrazolium testing, also require standardization, taking into account X-ray intensity and exposure times. Thus, the adaptation and definition of these methodologies for the study of native Brazilian seeds is vital for the success of preservation programs (Ataide et al., 2012).

Given the above, the aim of the present study was to adapt to the tetrazolium test methodology for the assessment of baru seeds and evaluate the physiological quality of seeds stored during 12 months at 10 and $20^{\circ} \mathrm{C}$ using X-ray images as a tool for damage detection during the storage period, in addition to germination, emergence and electrical conductivity tests.

\section{MATERIALS AND METHODS}

\subsection{Fruit sampling}

Baru fruits were collected at the Bem Posta Farm, located in the municipality of Portelândia, GO, Brazil, at $17^{\circ} 15^{\prime} \mathrm{S}$ - $52^{\circ}$ $40^{\prime} \mathrm{N}$ and $549 \mathrm{~m}$ altitude. Two fruit batches were purchased, harvested in August 2014 and 2015, with ripe and whole fruits scattered on the ground. After sampling, the fruits were taken to the Federal Goiano Institute Seed Laboratory, located in the Rio Verde municipality, where the fruit processing and experiments were carried out. Seeds were obtained after opening the fruits with the aid of a PIT BULL ${ }^{\circledR}$ hand press.

\subsection{Water content}

The water content of the seeds was determined by oven method at $105 \pm 3{ }^{\circ} \mathrm{C}$ for 24 hours, adapted according to Brasil (2009), using four replications consisting of five seeds, corresponding to 10 grams. The seeds were weighed on an analytical balance with $0.001 \mathrm{~g}$ precision and calculations were performed according to the following formula 1 :

$$
\% \text { de Umidade }(U)=\frac{100(P-p)}{P-t}
$$

Where P: initial weight, weight of the container more weight of the moist seed (g); p: final weight, weight of the container more the weight of the dry seed (g); t: tare weight, container. (\% wet weight; w.b.).

\subsection{Assay 1. Definition of the tetrazolium test methodology for baru seeds}

The purpose of this test was to standardize the use of the tetrazolium test for baru seeds, using seeds from the two fruit batches collected in August 2014 and 2015. Baru fruits harvested in 2014 were stored in unsealed Styrofoam boxes and maintained at room temperature of $25 \pm 3{ }^{\circ} \mathrm{C}$ for 12 months. The fruits harvested in 2015 remained under the same condition for 60 days. Seed extraction was performed via fruit opening with the aid of a PIT BULL ${ }^{\circ}$ hand press. After seed removal, they were stored in a BOD incubator at $20^{\circ} \mathrm{C}$. Three tetrazolium salt solution concentrations, equivalent to $0.05,0.075$ and $0.10 \%$, and two presoaking times were tested. Initially, three repetitions consisting of 10 seeds were distributed on germitest sheets, moistened with three times their dry weight and maintained in the BOD incubator for 24 and 36 hours. The established pre-imbibition period was intended to facilitate seed tegument removal and activate the cellular seed metabolism. Tegument removal was performed with the aid of a scalpel blade from the superficial and longitudinal section towards the raphe. After tegument removal, the pre-soaked seeds were immersed in $30 \mathrm{~mL}$ of a tetrazolium salt solution at the aforementioned concentrations above for two and a half hours in the BOD incubator at $35^{\circ} \mathrm{C}$.

Seed vigor evaluation was performed through individual determinations using a magnifying glass, classified into four classes, as follows: very vigorous (VV), viable (V), deteriorated (D) and unviable (UNV).

\subsection{Assay 2. Seed Storage}

Baru fruits harvested in 2014 were stored in unsealed Styrofoam boxes and maintained at room temperature of 
$25 \pm 3{ }^{\circ} \mathrm{C}$ for 12 months and extracted from the fruits as mentioned previously.

The first lot was randomly divided into five samples, each representing a storage period, as follows: zero (control), three, six, nine and twelve months. The initial water content of the seeds was obtained from the control sample, equal to $7,49 \%$ (w.b.). Then, the seeds were packed in hermetically sealed glass jars and the voids were filled with cotton to reduce oxygen exchanges with the investigated material. The seeds from the five samples were then maintained in a BOD incubator at 10 and $20^{\circ} \mathrm{C}$. At each time point, subsamples of storage at 10 and $20^{\circ} \mathrm{C}$ were removed an submitted to water content determination and vigor evaluations were conducted through electrical conductivity tests, $\mathrm{x}$-ray imaging, germination and emergence assessments. The length and dry mass of the plants were determined to quantify baru seedling growth.

\subsection{Electrical Conductivity Test (EC)}

The electrical conductivity of the seed imbibition solution was determined according to a methodology adapted from Vieira and Krzyzanowski (1999). Four replicates consisting of five previously weighed seeds immersed in $75 \mathrm{~mL}$ of distilled water for 24 hours in a BOD incubator at $30^{\circ} \mathrm{C}$ were used. The soaking solution was assessed using a TECNAL model TEC-4MP benchtop conductivity meter.

\section{6. $X$-ray test and radiographic image analyses}

X-ray images were obtained at the Seed Analysis Laboratory belonging to the Lavras Federal University Department of Agriculture, using a Faxitron X-Ray Corporation X-ray scanner MX-20.

A total of 100 seeds were used to standardize the test reading. The seeds were separated into ten repetitions comprising ten units, fixed with double-sided tape on transparent acrylic plates and sequentially numbered. Exposure time and radiation intensity were set at $30 \mathrm{kv}$ for 45 seconds, respectively. Radiographic images were then saved and analyzed for internal seed morphology assessments.

\subsection{Germination test}

The seeds were placed on germitest sheets moistened with distilled water 2.5 times their dry weight and maintained in a Mangesldorf germinator at $30^{\circ} \mathrm{C}$. Germination was evaluated for eight days, with each seed individually evaluated according to the numerical X-ray image sequence. During this period, almost all seeds presented a root length of 0.5 $\mathrm{cm}$ or more. After germination, seedlings were maintained in the germinator for up to 15 days to even out their growth. Subsequently, seedling lengths (root and shoot) were evaluated with the aid of a digital caliper, while their dry weight was also determined using a $0.001 \mathrm{~g}$ precision analytical balance after drying in a forced-air drying oven at $65^{\circ} \mathrm{C}$ for 48 hours.

\subsection{Seedling emergence test}

Seedling emergence was conducted in a greenhouse with automated sprinkle irrigation $\left(28.4{ }^{\circ} \mathrm{C} \pm 4{ }^{\circ} \mathrm{C}\right.$ and relative humidity of $75 \pm 5 \%$ ) four times a day for eight minutes over beds containing washed sand as a substrate. Seed distribution on the substrate consisted of four repetitions with 25 seeds arranged horizontally with the hilum facing down up to a depth of $2.5 \mathrm{~cm}$. The criterion used to detect seedling emergence was set as when the two cotyledons were positioned above the substrate. The seedlings were maintained in the beds for 30 days, when seedling length and dry weight were determined.

\subsection{Statistical design}

The experimental design was completely randomized, consisting of four replications. The vigor classes of the tetrazolium test were subjected to analysis of variance by Tukey test at 5\% probability. And the analyzed variables of seed storage were submitted to regression analysis by the SISVAR statistical program. Regression models were adjusted, and the graphs were plotted using the Sigma Plot, software version 12.0 .

\section{RESULTS AND DISCUSSION}

\subsection{Assay 1. Tetrazolium Test}

The tetrazolium solution concentrations used in this study were equally efficient in identifying damage present in baru seeds. As all, concentrations allowed for salt reaction endosperm and embryo reserve tissues, regardless of the seed lot (Figure 1). Thus, aiming at lower costs, a $0.05 \%$ concentration and pre-imbibition time of 24 hours are recommended, as this condition is sufficient to activate initial seed metabolism and promote the salt reaction with seed tissues (Figure $1 \mathrm{AD}$ ).

In a study by Brito et al. (2020), in order to evaluate the vigor of Tabebuia aurea seeds under conditions similar to those described for baru seeds, the authors showed that the best concentration was $0.05 \%$ of the tetrazolium salt for four hours of soaking. For these authors, the tetrazolium test has become increasingly efficient in the methodologies for assessing the vigor of forest species. Although the concentration of the tetrazolium salt solution used is efficient for both, baru 
seeds need a longer exposure time. Since, the seeds have a very thick endosperm. Which probably influences the absorption time of the solution. Affirming the relevance and importance of vigor test adequacy for seeds, Medeiros et al. (2020) observed in seeds of Amburana cearenses (Allemão) A.C. Smith, significant correlations in the quantification of vigor of normal seedlings when compared to vigor using the tetrazolium test.

In Figure 1 it is possible to verify that the most vigorous tissues of baru seeds have pink color in its entirety, viable seeds have about $40 \%$ of the most intense color, the seeds deteriorated and unviable, more than $40 \%$ of the tissues with carmim red color. These color patterns were also observed by Carvalho et al. (2017) in Libidibia ferrea seeds that the ideal concentration for the test was $0.05 \%$ for six hours of soaking. And in Jatropha molissima seeds that $0.25 \%$ of the tetrazolium concentration was necessary to react with seed tissues for four hours (Walter et al., 2020).

The exposure time (24 hours) for baru seeds was higher compared to other studied seeds, probably can be related to a large amount of endosperm reserve material. Other tissue damage at the different concentrations evaluated is evidenced in Figures 2 and 3 presents the types of damage caused by moisture, insect attacks and mechanical damage in detail. However, it is noteworthy that these damages were found in a very small fraction of the assessed seeds considering the number of seeds used for this test, regardless of the fruit collection year.

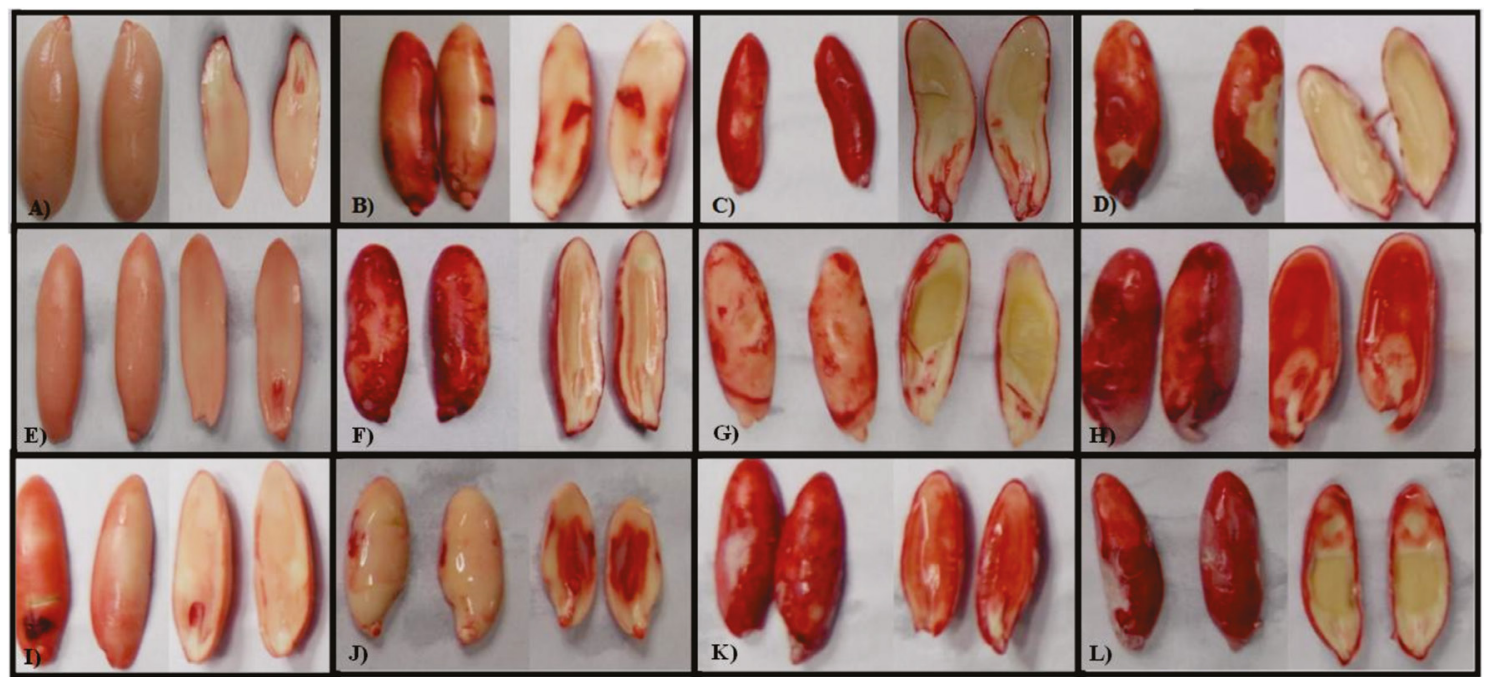

Figure 1. Tetrazolium test on baru (Dipteryx alata Vogel) seeds subjected to different concentrations for 24 hours. Where concentrations are indicated by the lines, $0.05 \%(\mathrm{~A}, \mathrm{~B}, \mathrm{C}$ and $\mathrm{D}) ; 0.075 \%$ (E, F, G and $\mathrm{H})$ and $0.10 \%$ (I, J, K and L). And the vigor classes in the columns, $(\mathrm{A}$, $\mathrm{E}$ and I) very vigorous seeds (VV); (B, F and J) viable seeds (V); (C, G and K) deteriorated seeds (D); (D, H and L) unviable seeds (UNV).

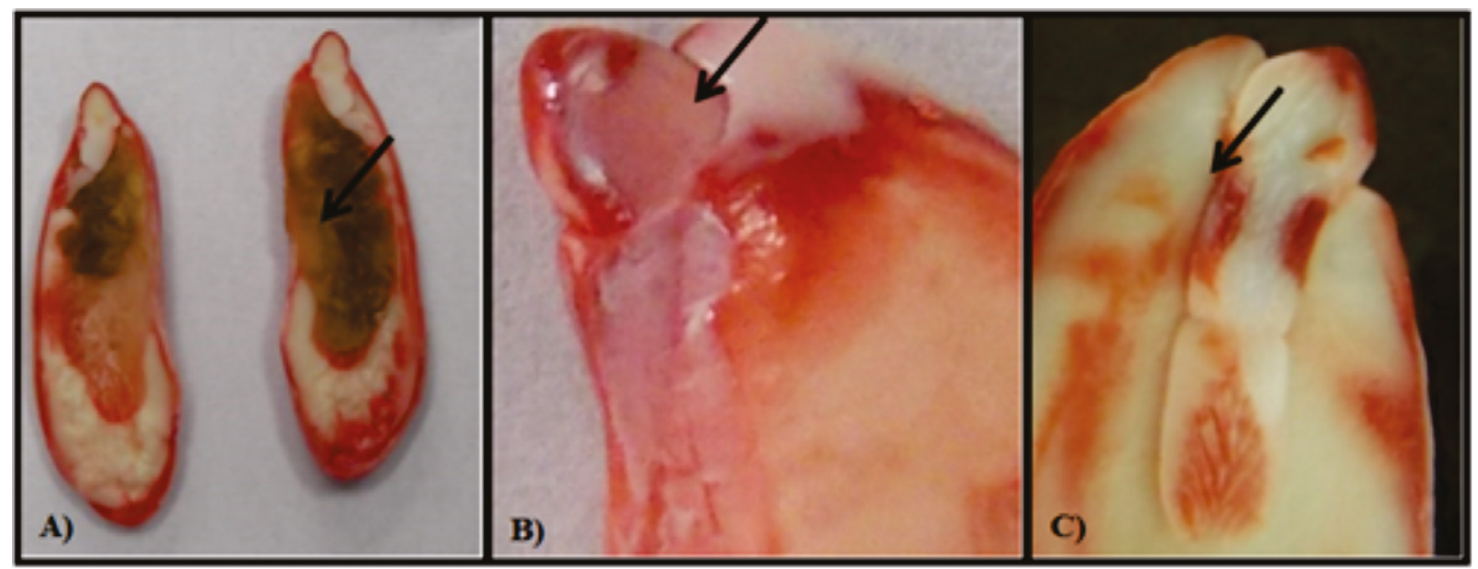

Figure 2. Tetrazolium test performed on baru seeds (Dipteryx alata Vogel). (A) seed presenting endosperm tissue necrosis, indicated by the arrow. (B and $\mathrm{C}$ ) Moisture damage in the embryo region, indicated by the arrow. 


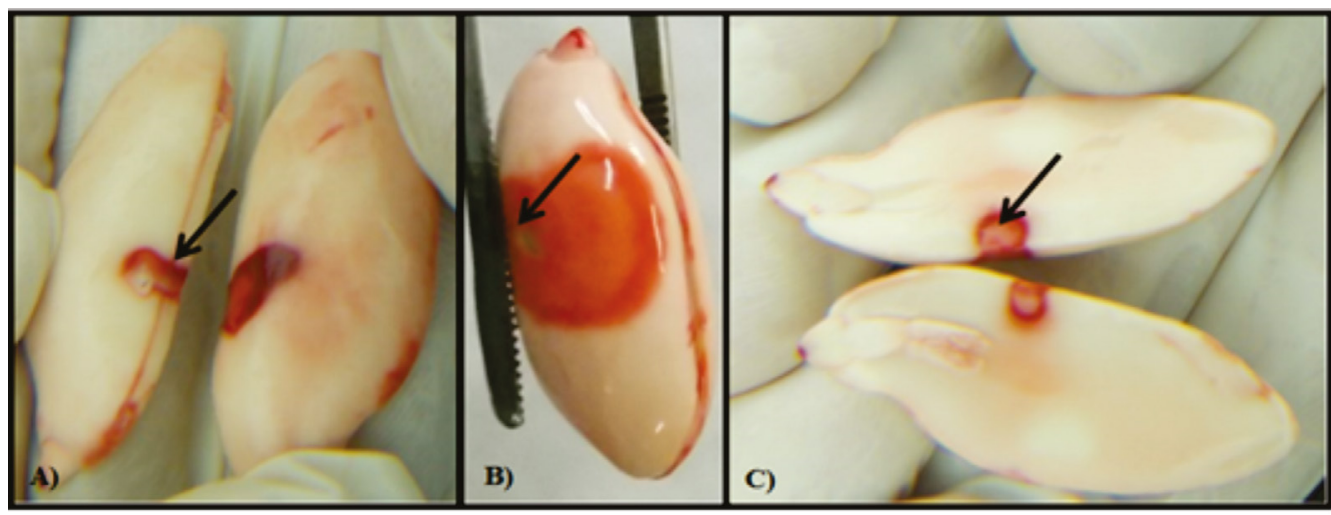

Figure 3. Details evidenced by the black arrow indicate mechanical damage (A) and insect damage (B and C) in baru seeds (Dipteryx alata Vogel) assessed by the tetrazolium test.

\subsection{Assay 2. Seed Storage}

One of the most important aspects to be evaluated during seed storage is seed water content. This factor is determinant to conservation conditions, since it exerts direct influence on seed metabolism (Carvalho \& Nakagawa, 2000; Nagel \& Börner, 2010). In the present study, the water content of baru seeds decreased throughout the 12 months of storage. An interaction between time and temperature was noted, and
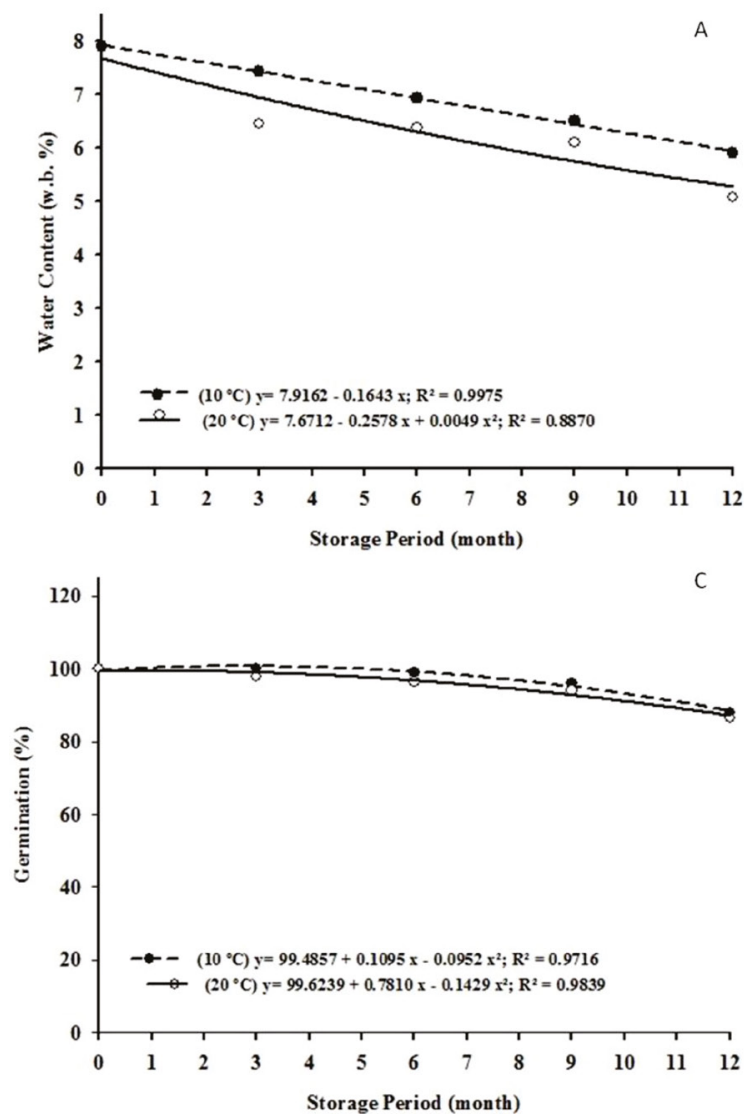

according to the obtained values, the seeds initially stored at 7.49 water content decreased to 6.12 and $5.39 \%$ (w.b.) at 10 and $20^{\circ} \mathrm{C}$, respectively (Figure 4A). Similar behavior has been observed for soybean seeds stored at $20{ }^{\circ} \mathrm{C}$ for six months, exhibiting decreasing water content during storage (Smaniotto et al., 2014). It is noteworthy that, although baru seeds displayed loss of water content, they still maintained high germination potential of above $85 \%$ at 12 months of storage (Figure $4 \mathrm{C}$ ).
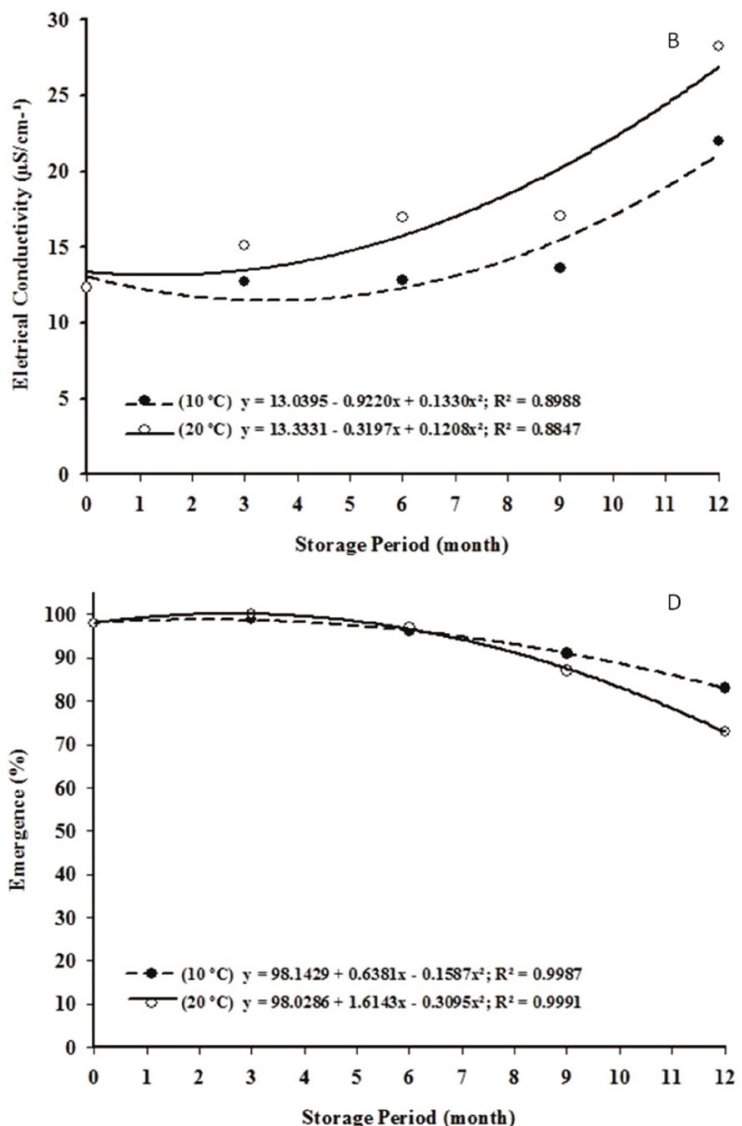

Figure 4. Water content, electrical conductivity, germination percentage and emergence percentage of baru seeds (Dipteryx alata Vogel) throughout 12 months of storage at 10 and $20^{\circ} \mathrm{C}$. w.b. = wet base. 
In this study, electrical conductivity, indicative of baru seed membrane permeability, increased during 12 months of storage (Figure 4B). This increase was not, however, directly linked to their deterioration, as germination and emergence tests detected high physiological quality seeds (Figure $4 \mathrm{C}$ and D), of above $85 \%$ and $70 \%$, respectively. Seed deterioration can occur during storage under unfavorable environmental conditions. One of the first signs of such damage is increased membrane permeability. This, however, will not always indicate a high degree of deterioration, as cell structures may be rewarded by repair mechanisms (Panobianco et al., 2007), which may still result in high seed vigor, corroborating the results of this study.

Studies conducted with soybean seeds by Fessel et al. (2010) corroborate the results reported herein, as those authors verified that 10 and $20^{\circ} \mathrm{C}$ for up to 15 months of storage led to an increase in solutes present in the electrical conductivity soaking solution, but no seed deterioration. In contrast, Pontes et al. (2006) reported that increased electrical conductivity in Caesalpinia peltophoroides (Benth.) seeds is associated to decreased germination. This species, also classified as orthodox, reached rates below $70 \%$ at 8 months of storage at $20^{\circ} \mathrm{C}$. Sequentially to these results, Silva et al. (2018) checked an increase in the values of electrical conductivity in Jatropha curcas seeds stored for 18 months. In which, with the increase in conductivity, there was a marked reduction in vigor, reaching $15 \%$ of germination. Afzal et al. (2019) also emphasize the importance of storing seeds in hermetically packaging and low water content. Studies carried by these authors with Moringa oleifera seeds, detected lower values for electrical conductivity when stored at $10{ }^{\circ} \mathrm{C}$ with $8 \%$ moisture and hermetically sealed. While seeds with high water content are subject to deterioration.

These results demonstrate the importance of studies to define storage time and the temperature for seeds in general, as the results vary even among orthodox species, and vigor and, consequently, longevity may be affected by intrinsic inter-specific factors over time (Murthy et al., 2003).

Baru seeds maintained high germination rates in the present study (Figure $4 \mathrm{C}$ ). In accordance with the germination data obtained herein, seedling emergence evaluations indicate that baru seeds remained viable during storage (Figure $4 \mathrm{D}$ ). What was also verified in seeds of Melanoxylon brauna Schott, by Freire et al. (2021) who observed high percentages (85\%) of germination, when it is were maintained in a refrigerator at $\pm 4{ }^{\circ} \mathrm{C}$ for up to 12 months with a water content close to $5 \%$. Once in studies by Ribeiro et al. (2018) was noted that seeds of Erythrina velutina Willd., stored at $10^{\circ} \mathrm{C}$ for up to 14 months registered germination above $90 \%$, however, showed oscillation in the rate of seed moisture after six months of storage.
According to data obtained in the present study, baru seeds initially presented $99 \%$ emergence, decreased prominently after nine months. No interaction between time and temperature was observed, however, lower emergence percentages were observed at $20^{\circ} \mathrm{C}(73 \%)$ (Figure $\left.4 \mathrm{D}\right)$. In the studies carried out by Araújo et al. (2017) with seeds of Amburana cearensis (Allemão) A.C. Sm., there was reduction in the percentage of emergence when maintained at $25^{\circ} \mathrm{C}$, counterpart, the seeds of Amburana cearensis stored in a refrigerated and hermetically sealed environment remained viable for up to 24 months, corroborating the results of the present study.

Regardless of temperature, no effect of storage time on baru seedling length and dry mass was observed, even with a slight reduction in vigor, as evidenced by decreased germination and emergence over time.

$\mathrm{X}$-ray tests were performed to support the germination and emergence test results. No temperature effect was noted regarding internal and external seed morphology. Thus, only images referring to the $10^{\circ} \mathrm{C}$ storage temperature and its respective seedlings are presented (Figure $5 \mathrm{~A}-\mathrm{E}$ ). All internal and external structures generally remained intact throughout the storage periods.

It is well known that decreased reserve areas in seed compromises seed quality (Oliveira et al., 2003). Contrary to what was expected with the conditions of storage and reduction of water content $(7.49,6.12$ and $5.39 \%)$, there was no change or reduction in the area between the endosperm and the tegument (Fig. 5 A-E), regardless of the evaluated temperature. Even in analyzes carried out immediately after collection, or even, up to 12 months of storage. Corroborating the high germination and emergence percentages. Otherwise, Machado \& Cicero (2003) report that seeds from forest species, due to uneven maturity and/or development, usually present internal damage. They also indicate that seeds with 75 to $50 \%$ filled embryonic cavities generate abnormal seedlings or do not germinate when evaluating white pepper seeds.

Seedling mortality from baru seeds in this trial was below $15 \%$ and occurred after nine months of storage, more accentuated at the $12^{\text {th }}$ month (Figure $5 \mathrm{~F}$ ). In addition, the low mortality percentage observed in this study is due to microorganism contamination, and not morphological changes. Effect similar to this fact, was reported by Pupim et al. (2008) in which fully formed embaúba seeds do not generate seedlings due to contamination and physiological deterioration. Still, Gomes et al. (2016) when evaluating radiographic images of Platypodium elegans Vog. verified that "full" seeds, that is, with all the internal structures necessary for seedling development, accounted for between 60 and $72 \%$ germination. Parallel to these studies, Medeiros et al. (2018) evaluated the internal morphology of Leucaena leucocephala 
seeds with moisture of about $8 \%$, and stated that lower the water content of the seeds, better radiation absorption. In these conditions, the authors recorded a germination percentage above $65 \%$ for $L$. leucocephala seed lots that showed integrity of the internal morphology.

Expressive values were also denoted in Crotalaria juncea L. seeds with water content between 8 and 9\%, where $77 \%$ of the seeds generated normal seedlings. These authors evidenced that each species has peculiarities, in terms of density and chemical composition and are directly related to the visualization of seed structures (Arruda et al., 2016). Because of that, it is considered for baru seeds that the water content contributed positively to the analysis of radiographic images. And that, the large amount of reserve material present in baru seeds and its orthodox character seem to confer longevity during storage for the seeds. These data, referring to the composition of baru seeds were analyzed in previous studies by Silva et al. (2020).
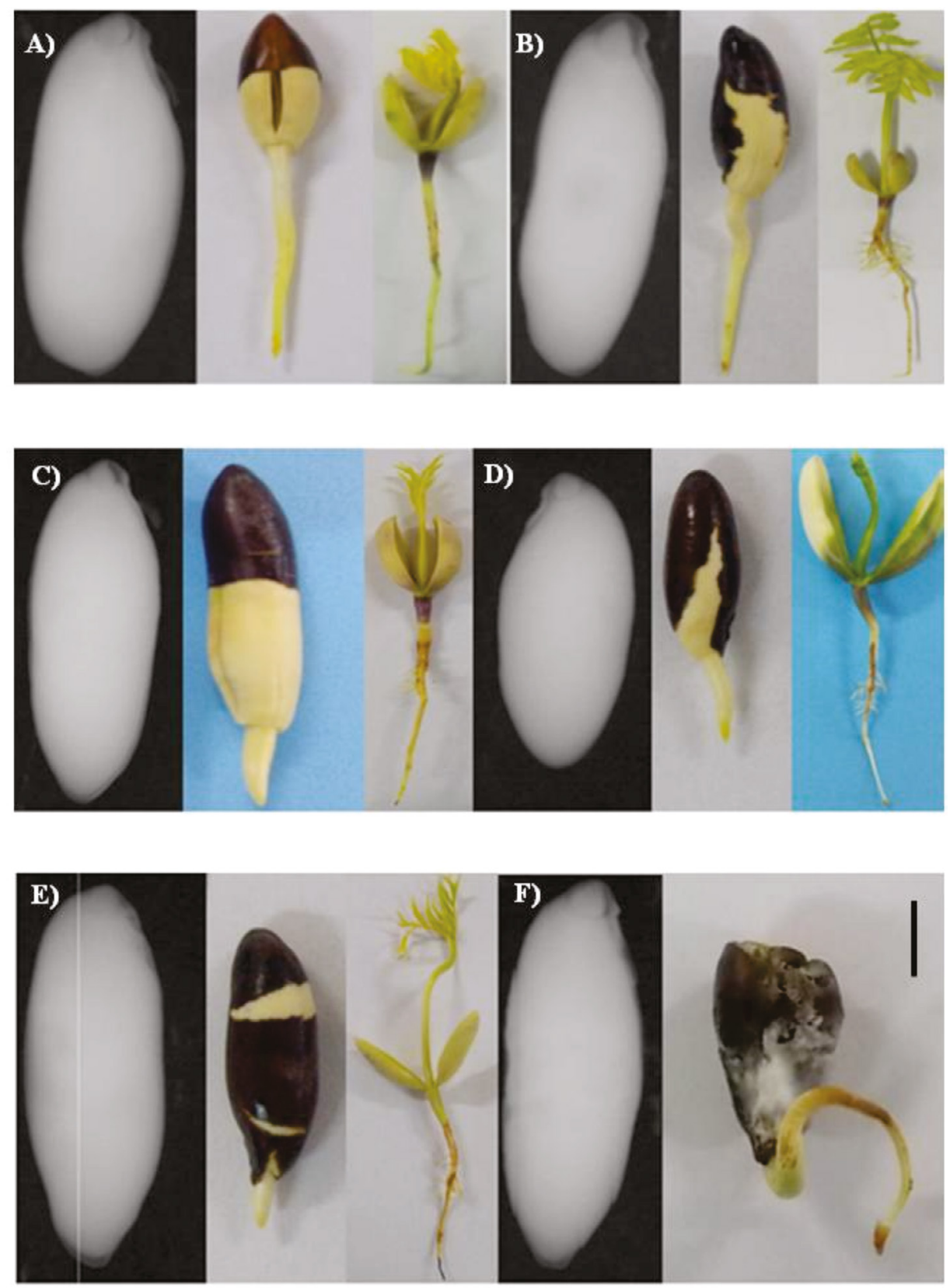

Figure 5. X-ray images of baru seeds (Dipteryx alata Vogel) during different storage periods at $10{ }^{\circ} \mathrm{C}$. (A) Control, (B) Stored at $10{ }^{\circ} \mathrm{C}$ for 3 months. (C) Stored at $10^{\circ} \mathrm{C}$ for 6 months. (D) Stored at $10^{\circ} \mathrm{C}$ for 9 months. (E) Stored at $10{ }^{\circ} \mathrm{C}$ for 12 months. (F) dead seeds by microorganism contamination. 


\section{CONCLUSIONS}

The tetrazolium test applied to baru seeds was efficient at all analyzed concentrations, although the recommended pre-imbibition time and concentration are, respectively, 0,05\% and 24 hours for Dipteryx alata Vogel.

The $\mathrm{X}$-ray test is proven to be a promising and accurate technique for visualizing internal baru seed structures. In addition, there was no effect of damage from storage on the morphological characteristics of the seeds analyzed by the $\mathrm{X}$-ray test.

\section{ACKNOWLEDGMENTS}

The authors thank the Goiano Federal Institute of Education, Science and Technology (IFGoiano-RV) for providing financial support. GP Silva and KJT are grateful to the Coordination for the Improvement of Higher Education Personnel (CAPES). AA Rodrigues is grateful to the Conselho Nacional de Desenvolvimento Científico e Tecnológico (CNPq) for the Pós-doutorado Júnior - PDJ scholarship, process number 151023/2018-2 scholarships.

\section{SUBMISSION STATUS}

Received: 15 Apr. 2020

Accepted: 30 Jun. 2021

Associate editor: João Vicente de Figueiredo Latorraca

\section{CORRESPONDENCE TO Arthur Almeida Rodrigues}

Instituto Federal Goiano de Educação, Ciência e Tecnologia, Laboratório de Sementes, Campus Rio Verde, PO Box 66, CEP 75901-970, Rio Verde, GO, Brasil

e-mail: arthuralmeidaeng@gmail.com

\section{REFERENCES}

Abreu LAS, Carvalho LM, Pinto CAG, Kataoka VY. Teste de condutividade elétrica na avaliação de sementes de girassol armazenadas sob diferentes temperaturas. Revista Brasileira de Sementes 2011; 33(4):593-601. http://dx.doi.org/10.1590/S010131222011000400005 .

Abreu LAS, Carvalho MLM, Pinto CAG, Kataoka VY, Silva, TTA. Deterioration of sunflower seeds during storage. Journal of Seed Science 2013; 35(2):240-247. https://doi.org/10.1590/S231715372013000200015 .

Afzal I, Jaffar I, Zahid S, Rehman HUr, Barsa SMA. Physiological and biochemical changes during hermetic storage of Moringa oleifera seeds. Shout. South African Journal of Botany 2019; 129: 435-441. https://doi.org/10.1016/j.sajb.2019.11.011.
Alves MVP. Armazenamento, viabilidade e emergência de sementes e diásporos de Emmotum nitens (Benth) Miers. Revista Verde de Agroecologia e Desenvolvimento Sustentável 2012; 7:163-168.

Araújo MS, Ferraz M, Américo FKA, Silva FS, Dantas BF, Cruz CRP. Seed quality of Amburana cearensis (Allemão) A.C. Sm. (Fabaceae) is influenced by storage condition. Journal of Seed Science 2017; 39(4):401-409. http://dx.doi.org/10.1590/2317-1545v39n4179328.

Arruda N, Cicero SM, Junior FGG. Radiographic analysis to assess the seed structure of Crotalaria juncea L. Journal of Seed Science 2016; 1-8. http://dx.doi.org/10.1590/2317-1545v38n2155116.

Ataíde GD, Flores AV, Borges EEL. Alterações fisiológicas e bioquímicas em sementes de Pterogyne nitens Tull. Durante o envelhecimento artificial. Pesquisa Agropecuária Tropical 2012; 42:71-76. http://dx.doi.org/10.1590/S1983-40632012000100010.

Azerêdo GA, Paula RC, Valeri SV. Viabilidade de sementes de Piptadenia moniliformis Benth. pelo teste de tetrazólio. Revista Brasileira de Sementes 2011; 33:61-68. http://dx.doi.org/10.1590/ S0101-31222011000100007.

Bragante RB, Hell AF, Silva, JPN, Caetano DC, Ribeiro, RCLF, Barbedo CJ. Physiological and metabolic responses of immature and mature seeds of Libidibia ferrea ((Mart. ex Tul.) L.P Queiroz) under contrasting storage temperatures. Brazillian Journal of Botany 2018; 41(1):43-55. https://doi.org/10.1007/s40415-018-0442-3.

Brasil. Ministério da Agricultura, Pecuária e Abastecimento. Regras para análise de sementes. Ministério da Agricultura, Pecuária e Abastecimento. Secretaria de Defesa Agropecuária. 2009. Brasília, DF: Mapa/ACS. 395p.

Brannstrom C, Jepson W, Filippi AM, Redo D, Xu Z, Ganessh S. Land change in the Brazilian savanna (Cerrado), 1986-2002: comparative analysis and implications for land-use policy. Land Use Policy 2008; 25:579-595. https://doi.org/10.1016/j.landusepol.2007.11.008.

Brito WAL, Pereira KTO, Nogueira NW, Torres SB, Paiva EP. Evaluation of viability of Tabebuia aurea seeds through tetrazolium test. Revista Caatinga 2020; 33(4):993-999. http://dx.doi. org/10.1590/1983-21252020v33n414rc.

Burg WJ, Van Der, Aartese JW, Zwol RAV, Jalink H, Bino RJ. Predicting tomato seedling morphology by $\mathrm{x}$-ray analysis of seeds. Journal of the American Society for Horticultural Science 1994; 119:258-263. https://doi.org/10.21273/JASHS.119.2.258.

Carvalho FMV, Júnior PDM, Ferreira LG. The Cerrado into-pieces: Habitat fragmentation as a function of landscape use in the savannas of central Brazil. Biological Conservation 2009; 142:1392-1403. https://doi.org/10.1016/j.biocon.2009.01.031.

Carvalho NM, Nakagawa J. Sementes: ciência, tecnologia e produção. 4.ed. Jaboticabal: 2000; FUNEP, 588p.

Carvalho NM, Nakagawa J. Sementes: ciências, tecnologias e produção. 5.ed., Jaboticabal; 2012; FUNEP, p. 590.

Carvalho SMC, Torres SB, Benedito CP, Nogueira NW, Souza AAT, Neta MLS. Viability of Libidibia ferrea ((Mart. ex Tul.) L.P. Queiroz var. ferrea) seeds by tetrazolium test. Journal of Seed Science 2017; 39(1):7-12. http://dx.doi.org/10.1590/2317-1545v39n1163784. 
Cícero MS, Junior HLB. Avaliação do relacionamento entre danos mecânicos e vigor, em sementes de milho, por meio da análise de imagens. Revista Brasileira de Sementes 2003; 25:29-36. https:// doi.org/10.1590/S0101-31222003000100006.

Fernandes DC, Freitas JB, Czedera LP, Navesb MMV. Nutricional composition and protein value of the baru (Dipteryx alata Vog.) almond from the Brazilian Savana. Journal of the Science of Food and Agriculture 2010; 90:1650-1655. https://doi.org/10.1002/jsfa.3997.

Fessel SA, Panobianco M, Souza CR, Vieira RD. Teste de condutividade elétrica em sementes de soja armazenadas sob diferentes temperaturas. Bragantia 2010; 69:207-214. http://dx.doi. org/10.1590/S0006-87052010000100026.

França Neto JB, Krzyzanowski FC, Costa NP. O teste de tetrazólio em sementes de soja. Londrina: EMBRAPA-CNPSo, 72p. (EMBRAPACNPSo, 1998; Documentos, 116).

Freire JM, Rouws JRC, Breier TB, Ataídes GM. Dying and storage of Melanoxylon braúna Schott. seeds. Brazilian Journal of Biology 2021; 81(2):464-473. https://doi.org/10.1590/1519-6984.232578.

Freitas DA, Durães AFS, Firmo, DHT, Pinho NB, Carvalho LR. Levantamento de dados de espécies florestais nativas do Cerrado: um meio para bancos de sementes implantados que permitem restauração de ecossistemas florestais. Brazilian Journal of Animal and Environmental Research 2019; 2(5):1569-1583.

Gomes KBP, Matos JMM, Martins IS, Martins RC. X-ray test to evaluate the physiological potencial of Platypodium elegans Vog. Seeds (Fabaceae). Scientia Agropecuária 2016; 7(3):305-311. DOI: 10.17268/sci.agropecu.2016.03.19.

ISTA. International Seed Testing Association. International Rules for Seed Testing. Zurich, 2004, p. 174.

Klink CA, Machado R. Conservation of the Brazilian Cerrado. Conservation Biology 2005; 19:707-713. https://doi.org/10.1111/ j.1523-1739.2005.00702.x.

Kohama S, Maluf AM, Bilia DAC, Barbedo CJ. Secagem e armazenamento de sementes de Eugenia brasiliense LAM. (Grumixameira). Revista Brasileira de Sementes 2006; 28:72-78. http://dx.doi.org/10.1590/S0101-31222006000100010.

Lima LKS, Dutra AS, Santos CS, Barros GL. Agropecuária científica no semiárido 2013; 9:01-06.

Machado CF, Cicero SM. Aroeira-branca [Lithraea molleoides (Vell.) Engl. - Anacardiaceae] seed quality evaluation by the X-ray test. Scientia Agricola 2003; 60:393-397. http://dx.doi.org/10.1590/ S0103-90162003000200026.

Medeiros AD, Araújo JO, León MJ, Silva LJ, Dias DCFS. Parameters based on X-ray images to assess the physical and physiological quality of Leucaena leucocephala seeds. Ciência e Agrotecnologia 2018; 42(6):643-652. http://dx.doi.org/10.1590/1413-70542018426023318.

Medeiros JAD, Nunes SP, Félix FC, Ferrari CS, Pacheco MV, Torres SB. Vigor test of (strong) normal intact Amburana cearenses (Allemão) A.C. Smith seedlings. Journal of Seed Science 2020; 42:110. https://doi.org/10.1590/2317-1545v42221611.

Mota LHS, Scalon SPQ, Heinz R. Sombreamento na emergência de plântulas e no crescimento inicial de Dipteryx alata Vog. Ciência Florestal 2012; 22:423-431. http://dx.doi.org/10.5902/198050986611.
Murthy UMN, Kumar PP, Sun WQ. Mechanisms of seed ageing under different storage conditions for Vigna radiata (L.) Wilczeck: lipid peroxidation, sugar hydrolysis, Maillard reactions and their relationship to glass state transition. Journal of Experimental Botany 2003; 54:1057-106. https://doi.org/10.1093/jxb/erg092.

Nagel M, Börner A. The longevity of crop seeds stored under ambient conditions. Seed Science Research 2010; 20:1-12. http://dx.doi. org/10.1017/S0960258509990213.

Oliveira AN, Silva AC, Rosado SCS, Rodrigues EAC. Variações genéticas para características do sistema radicular de mudas de baru (Dipteryx alata Vog.). Revista Árvore 2006; 30:905-909. http:// dx.doi.org/10.1590/S0100-67622006000600005.

Oliveira LM, Carvalho MLM, Davide AC. Utilização do teste de raios-x na avaliação da qualidade de sementes de canafístula (Peltophorum dubium (Sprengel) Taubert. Revista Brasileira de Sementes 2003; 25:116-120. http://dx.doi.org/10.1590/S010131222003000100018 .

Panobianco M, Vieira RD, Perecin D. Electrical conductivity as an indicator of pea seed aging of stored at different temperatures. Scientia Agricola 2007; 64:119-124. http://dx.doi.org/10.1590/ S0103-90162007000200003.

Pinto TLF, Mondo VV, Gomes-Júnior FG, Cícero SM. Análise de imagem na avaliação de danos mecânicos em soja. Pesquisa Agropecuária Tropical 2012; 42:310-316. http://dx.doi.org/10.1590/ S1983-40632012000300010.

Pinto TLF, Cicero MS, Forti VA. Avaliação de danos por umidade, em sementes de soja, utilizando a técnica da análise de imagens. Revista Brasileira de Sementes 2007; 29:28-34. http://dx.doi.org/10.1590/ S0101-31222007000300004.

Pontes CA, Corte VB, Borges EEL, Silva AG, Borges RCG. Influência da temperatura de armazenamento na qualidade das sementes de Caesalpinia peltophoroides Benth. (Sibipiruna). Revista Árvore 2006; 30:43-48. http://dx.doi.org/10.1590/S0100-67622006000100006.

Pupim TL, Novembre ADLC, Carvalho MLM, Cicero SM. Adequação do teste de raio $\mathrm{x}$ para avaliação da qualidade de sementes de embaúba (Cecropia pachystachya Trec.). Revista Brasileira de Sementes 2008; 30(2):028-032.

Ribeiro RC, Gomes SEV, Dantas BF. Physiological quality of Erythrina velutina Willd. seeds (FABACEAE) under different storage conditions. Scientia Forestalis, 2018; 46(120):562-570. DOI: dx.doi. org/10.18671/scifor.v46n120.05.

Silva LJ, Dias DCFS, Sekita MC, Finger FL. Lipid peroxidation and antioxidant enzymes of Jatropha curcas L. seeds stored at different maturity stages. Acta Scientiarum Agronomy 2018; 40:1-10. Doi: 10.4025/actasciagron.v40i1.34978.

Silva GP, Sales JF, Nascimento KJT, Rodrigues AA, Camelo GN, Borges EEDL. Biochemical and physiological changes in Dipteryx alata Vog. seeds during germination and accelerated aging. South African Journal of Botany 2020; 131:84-92. https://doi.org/10.1016/j. sajb.2020.02.007

Smaniotto TA, Resende O, Marçal KAF, Oliveira DEC, Simon GA. Qualidade fisiológica das sementes de soja armazenadas em diferentes condições. Revista Brasileira de Engenharia Agrícola 
e Ambiental 2014; 18:443-453. http://dx.doi.org/10.1590/S141543662014000400013.

Soares TN, Chaves LJ, Telles MPC, Diniz-Filho JAF, Resende LV. Landscape conservation genetics of Dipteryx alata Vog. ("baru tree": Fabaceae) from Cerrado region of central Brazil. Genética 2008; 9-19 http://dx.doi 10.1007/s10709-007-9144-7.

Toledo MZ, Fonseca NR, César ML, Soratto RP, Cavariani C, Crusciol CAC. Qualidade fisiológica e armazenamento de sementes de feijão em função da aplicação tardia de nitrogênio em cobertura. Pesquisa Agropecuparia Tropical 2009; 39:124-133.
Vieira RD, Krzyzanowski FC. Teste de Condutividade Elétrica. In: Krzyzanowsky FC, Vieira RD, França-Neto JB. Vigor de Sementes: Conceitos e Testes. 1999; Londrina: ABRATES, p.4/1-4/26.

Walters C, Wheeler LM, Grotenhuins JM. Longevity of seeds stored in a genebank: species characteristics. Seed Science Research 2005; 15:1-20. https://doi.org/10.1079/SSR2004195.

Walter LS, Gabira MM, Silva MA, Nogueira AC, Kratz D. Adjustments in the tetrazolium test methodology for assessing the physiological quality of Jatropha mollissima (Euphorbiaceae). Bosque 2020; 41(1):77-88. DOI: 10.4067/S0717-92002020000100077. 